\title{
ANALGESIC EFFECT OF ROPIVACAINE AFTER \\ ARTHROSCOPIC RECONSTRUCTION OF THE \\ LIGAMENT IN ATHLETES
}

\author{
EFEITO ANALGÉSICO DA ROPIVACAÍNA APÓS RECONSTRUÇÃO ARTROSCÓPICA DO LIGAMENTO \\ EMATLETAS
EL EFECTO DE LA ROPIVACAÍNA EN EL DOLOR DESPUÉS DE LA RECONSTRUCCIÓN ARTROSCÓPICA
DE LIGAMENTOS DE UN ATLETA.

\section{Junjie Liu'1,2 (D) \\ (Public Health) \\ Mingang Guo (iD \\ (Basic Medicine)}

1. School of Physical Education, Wuhan University of Science and Technology, Wuhan Hubei, China. 2. Department of Physical Education, Wuhan University of Technology, Wuhan, Hubei, China.

\section{Correspondence:}

Wuhan 430081, Hubei, China. Inq773899@21cn.com It723931@21cn.com

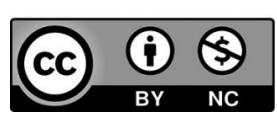

\begin{abstract}
After arthroscopic ligament reconstruction, athletes still need to go through a postoperative rehabilitation training period and suffer the possible pain that can go from moderate to severe. Commonly used analgesic medications, ropivacaine and fentanyl have the effect of relieving athletes' pain. To study the analgesic effect of ropivacaine on arthroscopic reconstruction of the knee ligament, the steps of reconstruction and pharmacology of ropivacaine were first introduced. Next, the analgesic effects of ropivacaine and fentanyl in 86 athletes were compared on muscle strength recovery, patient satisfaction, and pain score. The results showed that the satisfaction of patients with ropivacaine was $95.35 \%$, and the incidence of postoperative adverse reactions was only 9.30\%. These results indicate that ropivacaine has a better analgesic effect in arthroscopic reconstruction of the knee ligament in athletes, which is suitable for postoperative rehabilitation.
\end{abstract}

Keywords: knee joint; ligament; reconstruction; ropivacaine; analgesia

\section{RESUMO}

Após a reconstrução artroscópica do ligamento, os atletas ainda precisam passar por um longo período de treinamento pós-operatório de reabilitação e suportar a possivel dor de moderada a severa. Os medicamentos analgésicos ropivacaina efentanilo comumente utilizados têm o efeito de aliviar a dor dos atletas. Para estudar o efeito analgésico da ropivacaína na reconstrução artroscópica do ligamento do joelho foram introduzidos, em primeiro lugar, os passos da reconstrução artroscópica do ligamento e os da farmacologia da ropivacaína. Em seguida, os efeitos analgésicos da ropivacaína eo fentanilo em 86 atletas foram comparados com a recuperação na força muscular, na satisfação do paciente e na pontuação da dor. Os resultados mostraram que a satisfação dos doentes com a ropivacaína chegava a 95.35\%, e a incidência de reações adversas pós-operatórias foi apenas de 9.30\%. Estes resultados indicam que a ropivacaína tem melhor efeito analgésico na reconstrução artroscópica do ligamento do joelho, o que é adequado para a reabilitação pós-operatória.

Descritores: Articulação do joelho; ligamento; reconstrução; ropivacaína; analgesia.

\section{RESUMEN}

Después de la reconstrucción artroscópica del ligamento, los atletas aun precisan pasar por un largo período de entrenamiento posoperatorio de rehabilitación y soportar el posible dolor que puede ir de moderado a severo. Los medicamentos analgésicos, ropivacaína y fentanilo que son comúnmente utilizados, tienen el efecto de aliviar el dolor de los atletas. Para estudiar el efecto analgésico de la ropivacaína en la reconstrucción artroscópica del ligamento de la rodilla fueron introducidos, en primer lugar, los pasos de la reconstrucción y de la farmacología de la ropivacaína. Enseguida, los efectos analgésicos de la ropivacaína y el fentanilo en 86 atletas fueron comparados en la recuperación de la fuerza muscular, en la satisfacción del paciente y en la puntuación del dolor. Los resultados mostraron que la satisfacción de los pacientes con la ropivacaína llegaba a 95.35\%, y la incidencia de reacciones adversas posoperatorias fue apenas de 9.30\%. Estos resultados indican que la ropivacaína tiene mejor efecto analgésico en la reconstrucción artroscópica del ligamento de la rodilla de los atletas, lo que es adecuado para la rehabilitación posoperatoria.

Descriptores: articulación de la rodilla; ligamento; reconstrucción; ropivacaína; analgesia.

\section{INTRODUCTION}

Knee arthroscopic surgery is one of the important methods for the treatment of joint diseases, with the advantages of small surface trauma, rapid recovery and more accurate. ${ }^{1}$ However, the internal structure of knee joint repair, such as joint capsule and synovial tissue, is rich in nerve endings, and patients feel more severe pain in the process of surgical recovery. The incidence of moderate to severe pain after knee arthroscopy is about $76 \%$. ${ }^{2}$ Severe pain will have a certain impact on the postoperative rehabilitation of patients, especially the athletes returning to the field. The academic community attaches great importance to surgical pain, 
which is as important as blood pressure, heart rate, body temperature and other vital characteristics. At present, opioid receptor agonists, non steroidal anti-inflammatory drugs and so on are commonly used in knee arthroscopic surgery. ${ }^{3}$ Ropivacaine is a new type of long-acting amide local anesthetic, its physical and chemical properties are similar to lidocaine and bupivacaine, but the latter has stronger anesthetic performance, less adverse reactions to motor nerve, central nervous system and cardiovascular system, and less toxic than traditional local anesthetic. In view of this, this study will study the analgesic effect of ropivacaine from the aspects of muscle strength and cognitive ability after arthroscopic ligament reconstruction.

In this study, the analgesic effect of ropivacaine after arthroscopic ligament reconstruction was studied. The analgesic effects of fentanyl and ropivacaine were compared in 86 patients after arthroscopic ligament reconstruction. The muscle strength recovery, flexion angle of the affected limb and adverse reactions of the two groups were analyzed. Through the quantitative analysis of the analgesic effect of ropivacaine on the rehabilitation of athletes after operation, the analgesic effect and specific functional effect of ropivacaine are demonstrated.

The innovation of this study is to transform the analgesic effect of ropivacaine into quantitative data through specific muscle strength evaluation, so as to make the analysis more scientific, specific and accurate. At the same time, ropivacaine and fentanyl were compared in this study, and the analgesic effect of the two drugs after arthroscopic ligament reconstruction was analyzed by fully considering the special physique and rehabilitation needs of athletes.

\section{RELATED WORKS}

The knee joint is very important to the human body, but it is also easy to be damaged due to improper use and external force impact. The athletes' long-term high-intensity training and competition have increased the pressure on the knee joint, and various kinds of knee joint damage often occur. Many scholars have made a detailed study on the treatment, causes and postoperative rehabilitation of athletes knee joint injury. Rose $m$ and other scholars have proposed a simplified method for anterior cruciate ligament reconstruction through tibia. The use of single bundle double tibial anterior graft can minimize the total steps, thus limiting variance, maximizing efficiency, and reducing potential technical errors. ${ }^{4}$ Takigami J's team reported a case of DVT found by bilateral pulmonary artery large area PE and multi probe computed tomography after knee arthroscopic reconstruction of multi-layer knee ligament, and found the risk factors of thrombosis: 43 years old, long-term operation, obesity and diabetes mellitus, and put forward suggestions for prevention of thrombosis during operation. ${ }^{5}$ Based on the anatomical understanding of reconstruction techniques, Jorge chahla and other scholars proposed the key technologies of bone patellar tendon bone transplantation and interference screw fixation in arthroscopic single bundle anteromedial ACL reconstruction. ${ }^{6} \mathrm{Ma}-$ tava's team outlined the commonly used analgesics used by athletes and their ethical significance in the sport environment, balancing the medical impact of analgesics with the pressure from players, coaches and managers. The most commonly used drugs and their ethical and rational use were discussed?

From the above research results, it can be found that the current knee joint maintenance and research mainly focus on the causes and surgical techniques. However, the pain relief after knee surgery should be paid attention to. In view of this, on the basis of clarifying the pharmacology of ropivacaine, this study compared the analgesic effect of ropivacaine and fentanyl on knee arthroscopic ligament reconstruction, in order to find more suitable analgesic drugs for athletes.

\section{MECHANISM OF ROPIVACAINE AFTER KNEE LIGAMENT RECONSTRUCTION}

\section{Experimental design of analgesic effect of ropivacaine}

Arthroscopic ligament reconstruction surgery does not mean that the function of the knee joint can be recovered, and continuous rehabilitation training, including range of motion training, muscle strength training, proprioception training and flexibility training, is needed. Due to the pressure of training and competition, the athletes who have completed the operation are eager to resume the use of the knee as soon as possible, so the degree of pain in the process of rehabilitation is even worse. In view of this, a total of 86 athletes, aged 18-30 years old, who completed arthroscopic ligament reconstruction surgery in the tertiary hospital, were selected in this study. The observation group athletes used $0.2 \%$ ropivacaine hydrochloride injection, while the control group used fentanyl continuous intravenous pump for analgesia.

At 4, 6, 12, 24 and 48 hours after operation, the resting visual analogue pain score (VAS), active and passive activity VAS score, active knee flexion angle and muscle strength score of the two groups of athletes were detected respectively. At 1,4,7 days after operation, MMSE was used to evaluate the cognitive function of the patients, and the incidence of cognitive dysfunction (POCD) in the two groups of athletes was evaluated. The incidence of adverse reactions (vomiting, hypoxia, etc.) was recorded two days after the operation. Satisfaction score was used to investigate the satisfaction of all athletes.

Table 1 is the standard table of muscle strength score. "**" indicates that the item has completely recovered to normal level; ${ }^{\prime *} *$ indicates that the patient has good recovery condition; "* "indicates that the patient has certain ability; "-"indicates that the patient does not have the ability. In the test of muscle strength score, athletes keep supine position, knee joint flexion and extension of the affected limb, and professional doctors give pressure to observe the muscle strength of quadriceps brachii. The MMSE scale includes seven items: time orientation, attention, computational power, language, visual space and so on. If the subject's score is lower than 23, it can be judged as POCD. The satisfaction questionnaire mainly includes the evaluation of postoperative analgesia, operation effect, recovery degree and other subjective contents. The full score is 100 points. The higher the score, the higher the patient satisfaction. If the score is 90-100, it is "satisfied"; if the score is more than 70 but not higher than 90, the degree of satisfaction is "general"; if the score is less than 70, the degree of satisfaction is "dissatisfaction".

\section{Analgesic effect of ropivacaine after knee ligament recons- truction}

Through six tests on 86 athletes, the results were analyzed by spss20.0 statistical software, and compared with $t$ test and $x^{2}$ test, the test results were statistically significant with $P<0.05$.

Figure 1 (a) shows a comparison of resting VAS scores. The higher the score, the higher the pain degree of the patients. The VAS score of athletes in 4-12h after operation increased, but the score decreased gradually from $12 \mathrm{~h}$ to $48 \mathrm{~h}$. This shows that both drugs play an analgesic

Table 1. Scoring criteria.

\begin{tabular}{c|c|c|c|c|c}
\hline Score & $\begin{array}{c}\text { Muscle } \\
\text { contraction }\end{array}$ & $\begin{array}{c}\text { Muscle } \\
\text { movement }\end{array}$ & $\begin{array}{c}\text { Horizontal } \\
\text { movement }\end{array}$ & Anti gravity & Resistance \\
\hline 0 & - & - & - & - & - \\
\hline 1 & $*$ & - & - & - & - \\
\hline 2 & $*$ & $*$ & $* *$ & - & - \\
\hline 3 & $* *$ & $* *$ & $* *$ & $*$ & - \\
\hline 4 & $* * *$ & $* * *$ & $* * *$ & $* *$ & $*$ \\
\hline 5 & $* * *$ & $* * *$ & $* * *$ & $* * *$ & $* * *$ \\
\hline
\end{tabular}




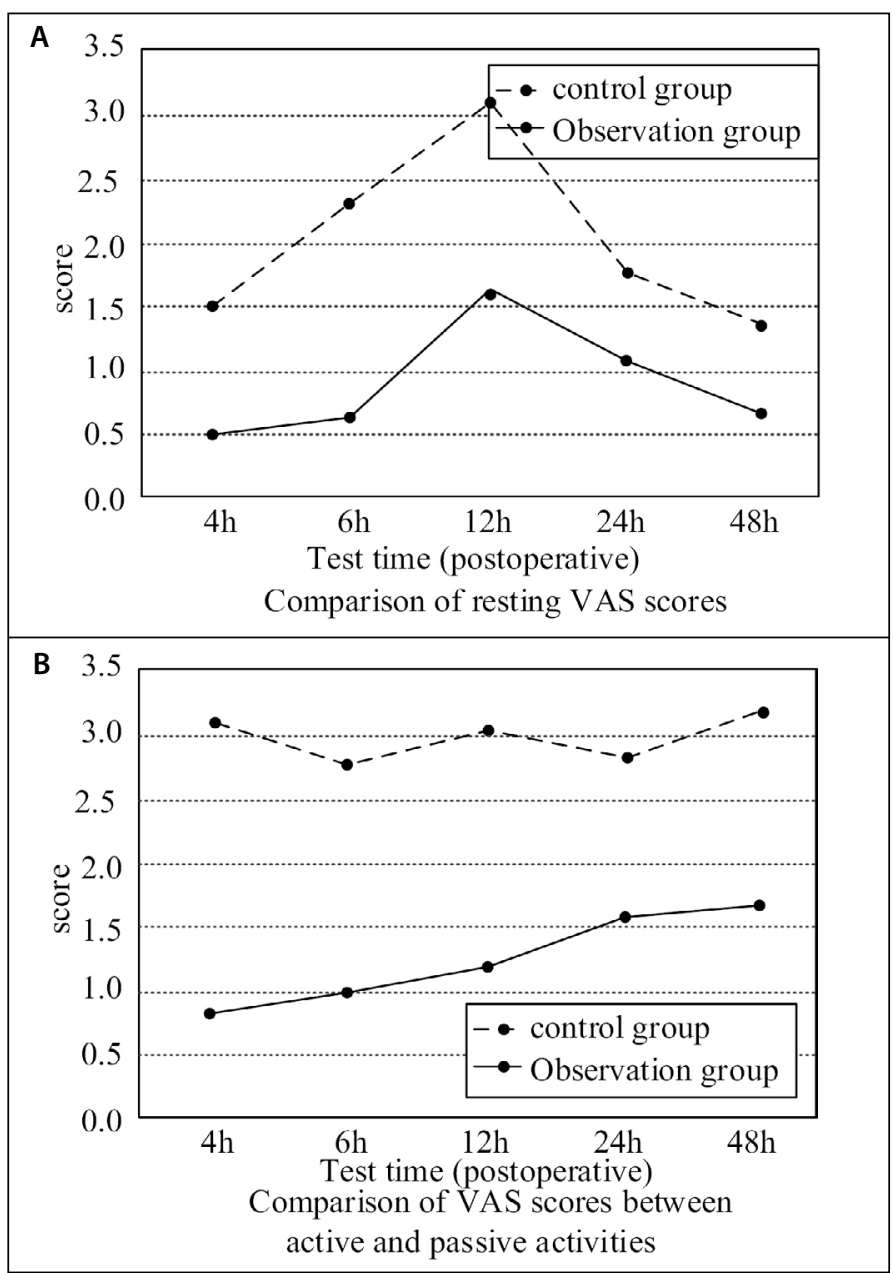

Figure 1. Comparison of VAS scores.

role within $12 \mathrm{~h}$ after operation, which may be due to the improvement of patients'adaptability. The restVAS score of the observation group was lower than that of the control group, and the comparison results of the two groups had statistical difference $(P<0.05)$. Figure $1(b)$ shows the comparison of VAS scores of active and passive activities. The scores of active and passive activities in the observation group were significantly lower than those in the control group, and the difference was statistically significant $(P<0.05)$.

The comparison of muscle strength score between the two groups is shown in Figure 2 (a). The muscle strength score of the observation group within 2 days after arthroscopic reconstruction is higher than that of the control group, and the $P$ values of each group at the five time nodes of the experiment are 0.001 respectively, and the comparison difference is statistically significant $(P<0.05)$. Within two days after the operation, the muscle strength of the patients gradually improved with the rehabilitation training, and the rehabilitation training of athletes was more smooth. Figure 2 (b) shows the comparison of flexion angles of affected limbs. The flexion angle of the main knee joint in the observation group within two days after operation was significantly higher than that in the control group, and the difference was statistically significant $(P<0.05)$.

Table 2 shows the statistics of adverse reactions. Athletes' adverse reactions to ropivacaine are mainly nausea, vomiting and hypoxemia * in some athletes. The adverse reactions of fentanyl in the control group are mainly nausea, vomiting and hypoxia, and there are individual cases of urinary retention and additional analgesics. In the control group, 13 athletes had adverse reactions, the incidence rate was $30.23 \%$. The observation group of 43 athletes a total of 4 adverse reactions, the incidence rate was $9.30 \%$, the difference was statistically significant $(P<0.05)$.
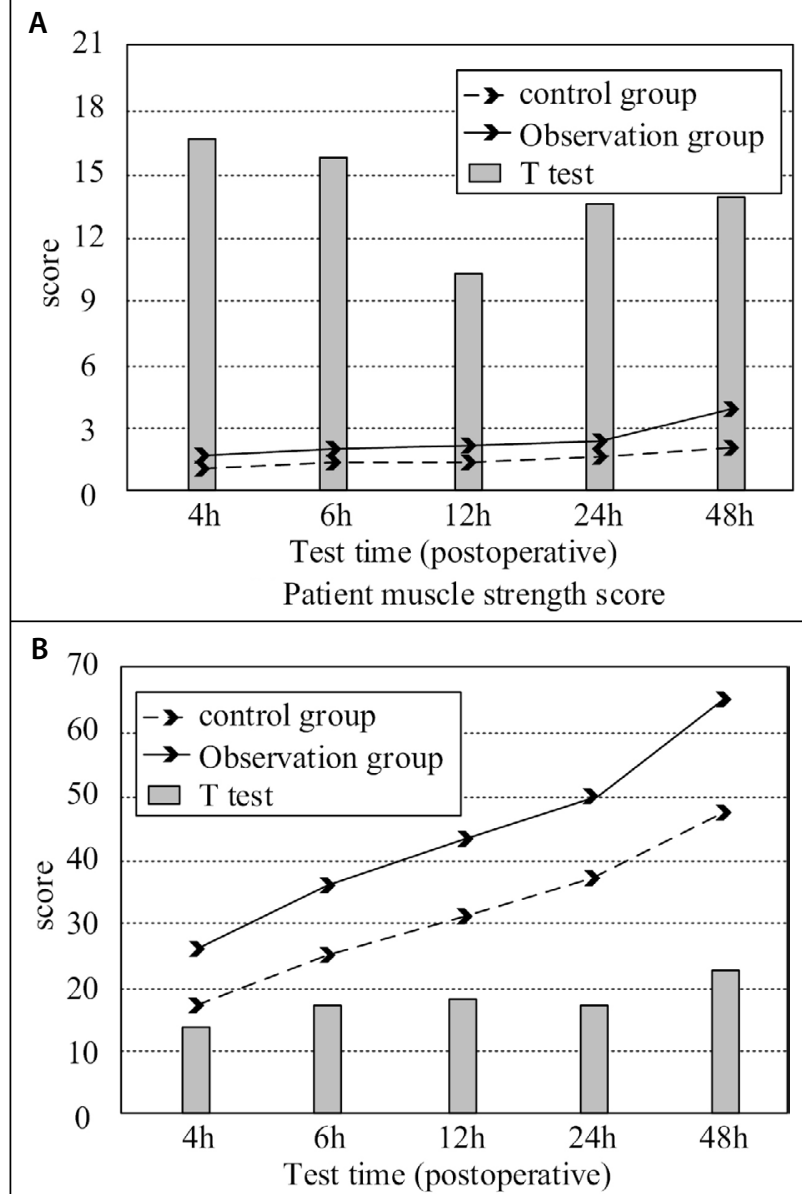

Comparison of active knee flexion angle

Figure 2. Comparison of muscle strength score and knee flexion angle.

Table 2. Comparison of postoperative adverse reactions.

\begin{tabular}{c|c|c|c|c|c|c|c}
\hline Group & $\mathbf{n}$ & $\begin{array}{c}\text { Urinary } \\
\text { retention }\end{array}$ & nausea & vomit & hypoxia & $\begin{array}{c}\text { Additional } \\
\text { analgesics }\end{array}$ & $\begin{array}{c}\text { Total } \\
\text { incidence }\end{array}$ \\
\hline $\begin{array}{c}\text { Observation } \\
\text { group }\end{array}$ & 43 & 0.00 & 4.65 & 2.33 & 2.33 & 0.00 & 9.30 \\
\hline Control group & 43 & 2.33 & 11.63 & 9.30 & 4.65 & 2.33 & 30.23 \\
\hline$X 2$ & - & - & - & - & - & - & 5.939 \\
\hline$P$ & - & - & - & - & - & - & 0.015 \\
\hline
\end{tabular}

Figure 3 shows the cognitive ability of patients using both drugs. The MMSE score of the observation group was significantly higher than that of the control group 1 day and 4 days after operation $(P<0.05)$, but there was no significant difference in MMSE score between the two groups at 7 days after operation $(P>0.05)$. Figure 3 (b) shows the patients with cognitive dysfunction. The incidence of POCD in the observation group was significantly lower than that in the control group at 1 and 4 days after operation, and the difference was statistically significant $(P<0.05)$, but no POCD occurred in the two groups on the seventh day after the operation, and the difference was not statistically significant $(P>0.05)$.

Table 3 shows the comparison of satisfaction of athletes using two kinds of analgesic drugs. The satisfaction rate of patients in the control group was $32.51 \%, 46.51 \%$ of the patients thought that the efficacy was general, $20.93 \%$ of the patients thought that the effect was not satisfactory, and the satisfaction rate of the patients was 79.07\%. In the observation group, $39.53 \%$ of the patients thought that the analgesic effect was good, $55.81 \%$ thought the efficacy was general, $4.65 \%$ thought that the patient was not satisfied, and the overall satisfaction of the patients was 95.35\%. The observation group was significantly higher than the control group, and the difference was statistically significant $(P<0.05)$. 


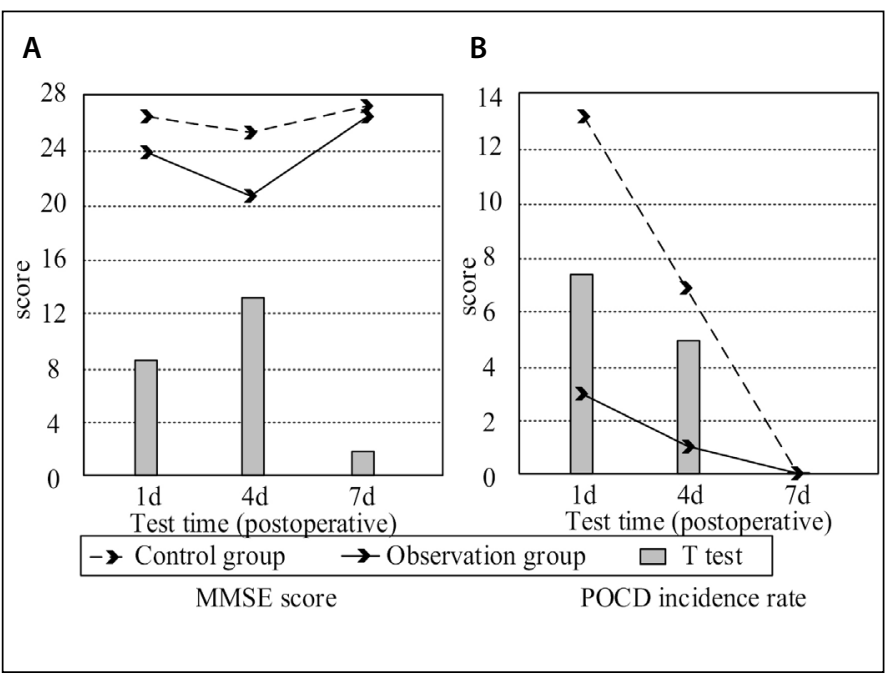

Figure 3. Comparison of postoperative cognitive ability of patients.

Table 3. Comparison of patient satisfaction.

\begin{tabular}{c|c|c|c|c}
\hline Group & Satisfied & Commonly & Dissatisfied & Satisfaction \\
\hline Observation group & 17 & 24 & 2 & 41 \\
\hline Control group & 14 & 20 & 9 & 34 \\
\hline$X 2$ & - & - & - & 5.108 \\
\hline$P$ & - & - & - & 0.024 \\
\hline
\end{tabular}

\section{CONCLUSION}

Postoperative pain is an acute pain that occurs immediately after surgery and usually lasts about seven days. When postoperative pain occurs, timely treatment is needed. If patients are not effectively treated, they may develop into chronic pain and neuropathic pain. There are many kinds of postoperative analgesia, including intravenous analgesia and continuous epidural analgesia. Among them, continuous epidural analgesia is widely used in clinic, and the side effects are mild. This study compared the analgesic effect of fentanyl intravenous injection and ropivacaine epidural continuous analgesia after knee arthroscopic ligament reconstruction, in order to find more suitable postoperative analgesic drugs for athletes. In this study, 43 patients were injected with fentanyl and ropivacaine. The VAS score of the observation group after injection of ropivacaine was maintained at a medium level after 4, 6, 12, 24 and 48 hours after operation. The incidence of POCD in the patients was significantly lower than that in the control group. There were 13 or 7 patients with POCD symptoms 1 day and 4 days after operation, which was significantly lower than that of the control group using fentanyl. The above results show that ropivacaine has good analgesic effect on the pain after arthroscopic ligament reconstruction for athletes, and the optimal dosage of ropivacaine to relieve postoperative pain needs to be analyzed.

All authors declare no potential conflict of interest related to this article

AUTHORS' CONTRIBUTIONS: The author has completed the writing of the article or the critical review of its knowledge content. This paper can be used as the final draft of the manuscript. Every author has made an important contribution to this manuscript. Mingang Guo: writing and execution. Junjie Liu: data analysis.

\section{REFERENCES}

1. Bogdanis GC, Donti O, Tsolakis C, Smilios I, Bishop DJ. Intermittent but Not Continuous Static Stretching Improves Subsequent Vertical Jump Performance in Flexibility-Trained Athletes. Journal of Strength and Conditioning Research. 2019; 33(1):203-210.

2. Mornieux G, Weltin E, Pauls M, Rott F, Gollhofer A. Influence of a Full Body Compression Suit on Trunk Positioning and Knee Joint Mechanics During Lateral Movements. Journal of applied biomechanics. 2017; 33(4):261-267.

3. Satora W, Królikowska A, Czamara A, Reichert P. Synthetic grafts in the treatment of ruptured anterior cruciate ligament of the knee joint. Polimery W Medycynie. 2017; 47(1):55.

4. Rose M, Crawford D. Technique for Arthroscopic-Assisted Primary Anterior Cruciate Ligament
Reconstruction Using Doubled Tibialis Anterior Tendon. Arthroscopy Techniques. 2017; 6(1):e87.

5. Takigami J, Hashimoto Y, Yamasaki S, Terai S, Nakamura H. A case of asymptomatic bilateral massive pulmonary embolism after arthroscopic multiple knee ligament reconstruction. Knee Surgery Sports Traumatology Arthroscopy, 2017, 25(1):260-262.

6. Chahla J, Moatshe G, Cinque ME, Godin J, Mannava S, LaPrade RF. Arthroscopic Anatomic Single-Bundle Anterior Cruciate Ligament Reconstruction Using Bone-Patellar Tendon-Bone Autograft: Pearls for an Accurate Reconstruction. Arthrosc Tech. 2017; 6(4):e1159-e1167.

7. Matava, Matthew J. Ethical Considerations for Analgesic Use in Sports Medicine. Clinics in Sports Medicine. 2016; 35(2):227-243 